Article

\title{
Comparison of the Microstructure of M2 Steel Fabricated by Continuous Casting and with a Sand Mould
}

\author{
Jinwen Zhang ${ }^{1,2, *}$, Zhigang Zhao ${ }^{2,3}$, Wenxian Wang ${ }^{1}$ and Yutian Wang ${ }^{2}$ \\ 1 College of Materials Science and Engineering, Taiyuan University of Technology, Taiyuan 030024, China; \\ wangwenxian@tyut.edu.cn \\ 2 Technology Center, Taiyuan Iron \& Steel (Group) Co., Taiyuan 030003, China; \\ zhaozhigang119@126.com (Z.Z.); wangyt@tisco.com.cn (Y.W.) \\ 3 National Engineering and Research Center for Continuous Casting Technology, Center Iron and Steel \\ Institute, Beijing 100081, China \\ * Correspondence: zhangjinwen0021@link.tyut.edu.cn; Tel.: +86-0351-213-3751
}

Received: 28 April 2019; Accepted: 10 May 2019; Published: 13 May 2019

\begin{abstract}
AISI M2 steel was smelted in a $150 \mathrm{~kg}$ medium-frequency induction furnace and cast to form round billets with a cross-section diameter of $100 \mathrm{~mm}$ via a vertical continuous caster and sand mold. The secondary dendrite arm spacing $\left(\lambda_{2}\right)$, cooling rates, permeability and size and distribution of grains and network carbides of the two billets were studied. The results show that the continuous casting process can effectively decrease the $\lambda_{2}$ value, permeability and size of the grains and carbides and improve the distribution of the grains and carbides during solidification. The $\lambda_{2}$ values of the billets cast with a sand mold and continuous caster are $37.34 \mu \mathrm{m}$ and $21.14 \mu \mathrm{m}$, respectively, and the cooling rate is $3.6 \mathrm{~K} \cdot \mathrm{s}^{-1}$ and $12.0 \mathrm{~K} \cdot \mathrm{s}^{-1}$, respectively. The area fractions of carbides at the center of the billets cast with the sand mold and continuous caster are 0.24 and 0.16 , respectively, and increase by $27.7 \%$ and $25.4 \%$, respectively, compared with their average values. The average grain size of billets cast with the sand mold and continuous caster is $69.4 \mu \mathrm{m}$ and $50.5 \mu \mathrm{m}$, respectively. Compared with the sand mold billet, the grain size at the center of the continuous casting billet is reduced by $25.5 \%$. The relationship between the grain size and cooling rate is presented in this paper.
\end{abstract}

Keywords: M2 high-speed steel; continuous casting; cooling rate; microstructure; grain size

\section{Introduction}

AISI M2 steel (Fe-0.9 C-6 W-5 Mo-4 Cr-2 V, wt\%) is a very popular high-speed steel because of its good combination of hardness and wear resistance at high temperatures [1,2]. Traditionally, M2 high speed steel manufacturing includes two steps, namely the mold casting and subsequent hot working like forging and rolling, which can break the coarse carbides network and refine structure. Typical as-cast structure of M2 high speed steel consists of dendrites surrounded by inter-dendritic network of eutectic carbides [3]. The main features of the as-cast structure are the distribution and size of the carbides and dendrites [4-6], which have a crucial influence on the mechanical properties of final products [7-9]. It is well known that the mechanical properties of high speed steel strongly depend on the carbide type, shape, size and distribution, which are closely related to the as-cast structure of ingots, especially those eutectic carbides.

Until now, most researchers have focused on the forging [10], heat treatment [11,12] and addition of alloy elements $[13,14]$, which can, to a certain extent, refine the carbides network and size but few concentrate on the initial solidified process of M2 high speed steel. An improved cooling rate can acquire a series of excellent properties such as finer micro-structure, extended solid solubility and 
improved strength $[15,16]$. Most M2 steel is still manufactured by the conventional method which uses sand molds [17]. With the development of metallurgical technology in recent years, the production of M2 steel has been realized by adopting continuous casting in some advanced steel mills [18]. The cooling rate of sand mold casting is slower than that of continuous casting. The dendrite size and center shrinkage cavity are developed as a result of the slow cooling conditions. The cooling rate is key to the quality of M2 steel [19] and an appropriate cooling rate has a positive effect on relieving internal defects in the billet such as cracks and center shrinkage cavities [20,21].

In this paper, a round M2 steel billet with a cross-section diameter of $100 \mathrm{~mm}$ was successfully cast by a vertical continuous caster. This study compares the solidification structure of M2 steel billets via a vertical continuous caster and sand mold. The quantitative relationship between the grain size and the cooling rate of the M2 steel during the solidification processes has been obtained, which has not been reported until now.

\section{Experimental Materials and Methods}

\subsection{Experimental Materials}

The material used in this study was M2 high-speed steel. The chemical composition of AISI M2 steel is (wt\%): C 0.8-0.9, Si 0.2-0.45, Mn 0.15-0.4, P $\leq 0.030, \mathrm{~S} \leq 0.030$, W 5.5-6.75, Mo 3.8-4.4, Cr 3.8-4.4 and V 1.75-2.2. The chemical composition of the test M2 steel is (wt\%) 0.806 C-0.306 Si- 0.334 Mn-0.02 P-0.02 S-5.71 W-4.567 Mo-4.01 Cr-1.78 V.

\subsection{Experimental Equipment and Preparation Methods}

The experimental equipment consisted of a vertical continuous caster designed by the National Engineering and Research Center for Continuous Casting Technology (Beijing, China). The process parameters of the vertical continuous caster are listed in Table 1.

Table 1. The process parameters of the vertical continuous casting machine.

\begin{tabular}{cccccc}
\hline $\begin{array}{c}\text { Mold Cross-Section } \\
\text { Diameter }\end{array}$ & Mold Length & Mold Taper & $\begin{array}{c}\text { Mold Oscillation } \\
\text { Frequency }\end{array}$ & $\begin{array}{c}\text { Mold Oscillation } \\
\text { Stroke }\end{array}$ & Casting Speed \\
\hline $100 \mathrm{~mm}$ & $400 \mathrm{~mm}$ & $1 \% / \mathrm{m}$ & $1.2 \mathrm{~Hz}$ & $\pm 3 \mathrm{~mm}$ & $0.4 \mathrm{~m} / \mathrm{min}$ \\
\hline
\end{tabular}

The test M2 steel was melted by a medium-frequency induction furnace and a certain amount of quick lime was added to form slag during melting process. As the high-speed steel was melted and raised to a predetermined temperature, the scum on the molten steel surface was scraped off. Then, $0.1 \mathrm{wt} \%$ aluminum block was added for deoxidation and degassing purposes. When the chemical composition and temperature stabilized to a constant value, the liquid steel was cast. The continuous casting round billet was cooled to room temperature. The liquidus temperature of M2 steel is $1430{ }^{\circ} \mathrm{C}$, which is calculated according to Equation (1). The casting temperature was $1460{ }^{\circ} \mathrm{C}$, so the superheat was $30^{\circ} \mathrm{C}$.

Molten steel was poured into a $\Phi 100 \mathrm{~mm} \times 300 \mathrm{~mm}$ sand mold to obtain $\mathrm{M} 2$ steel ingot and samples were obtained at one-third of ingot height. The test vertical continuous caster consists of four zones, namely, mold section, foot roll section, secondary cooling Section 1 and secondary cooling Section 2, with length of $400 \mathrm{~mm}, 80 \mathrm{~mm}, 140 \mathrm{~mm}$ and $240 \mathrm{~mm}$, respectively. The length of the continuous casting billet obtained from the test is $1.2 \mathrm{~m}$. A $10 \mathrm{~mm}$ thick slice was taken along the cross-section in the middle of continuous casting billet, five samples were obtained every $10 \mathrm{~mm}$ in turn from the edge to the center of the slice for continuous billet and sand mold ingot, respectively, the sampling method is shown in Figure 1.

$$
T_{\mathrm{L}}=1536-78 W_{\mathrm{C}}-9 W_{\mathrm{Si}}-5 W_{\mathrm{Mn}}-1.8 W_{\mathrm{Cr}}-2 W_{\mathrm{Mo}}-0.2 W_{\mathrm{W}}-2 W_{\mathrm{V}}-28 W_{\mathrm{S}}-40 W_{\mathrm{P}}
$$




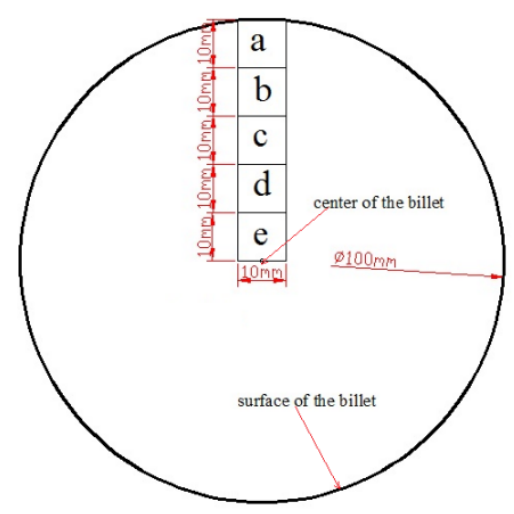

Figure 1. Schematic diagram of sampling for casting microstructure analysis.

The solidification microstructure of the samples was observed by optical microscopy using an $\mathrm{FeCl}_{3}-\mathrm{HCl}$ etchant $\left(3 \mathrm{~g} \mathrm{FeCl}_{3}+5 \mathrm{~mL} \mathrm{HCl}(50 \%)+100 \mathrm{~mL} \mathrm{H}_{2} \mathrm{O}\right)$. The $\lambda_{2}$, distribution and size of carbides and grains were studied by a Micro-image Analysis and Process System (MIAPS) (Zeiss, Jena, Germany).

\section{Results and Discussion}

\subsection{The $\lambda_{2}$ Value and Cooling Rate}

The cooling rate was difficult to directly measure during the M2 steel solidification process. The dendrite growth rate depends on the cooling rate and it determines the $\lambda_{2}$ value. Increasing the cooling rate increases the dendrite growth speed and decreases the value of $\lambda_{2}$. The cooling rate can be calculated by $\lambda_{2}$. The empirical relationships between $\lambda_{2}$ and the cooling rate can be expressed as Equation (2) [15]. In Equation (2), $\lambda_{2}$ represents secondary dendrite arm spacing ( $\left.\mu \mathrm{m}\right), \mathrm{d} T / \mathrm{d} t$ represents the cooling rate $\left(\mathrm{K} \cdot \mathrm{s}^{-1}\right)$ and $\mathrm{A}$ and $\mathrm{b}$ are the parameters for $\mathrm{M} 2$ high-speed steel, where $\mathrm{A}=43, \mathrm{~b}=0.32$ :

$$
\lambda_{2}=\mathrm{A}(\mathrm{d} T / \mathrm{d} t)^{-\mathrm{b}}
$$

Figures 2 and 3 show the dendritic structure in different samples from the sand mold and continuous casting billets.
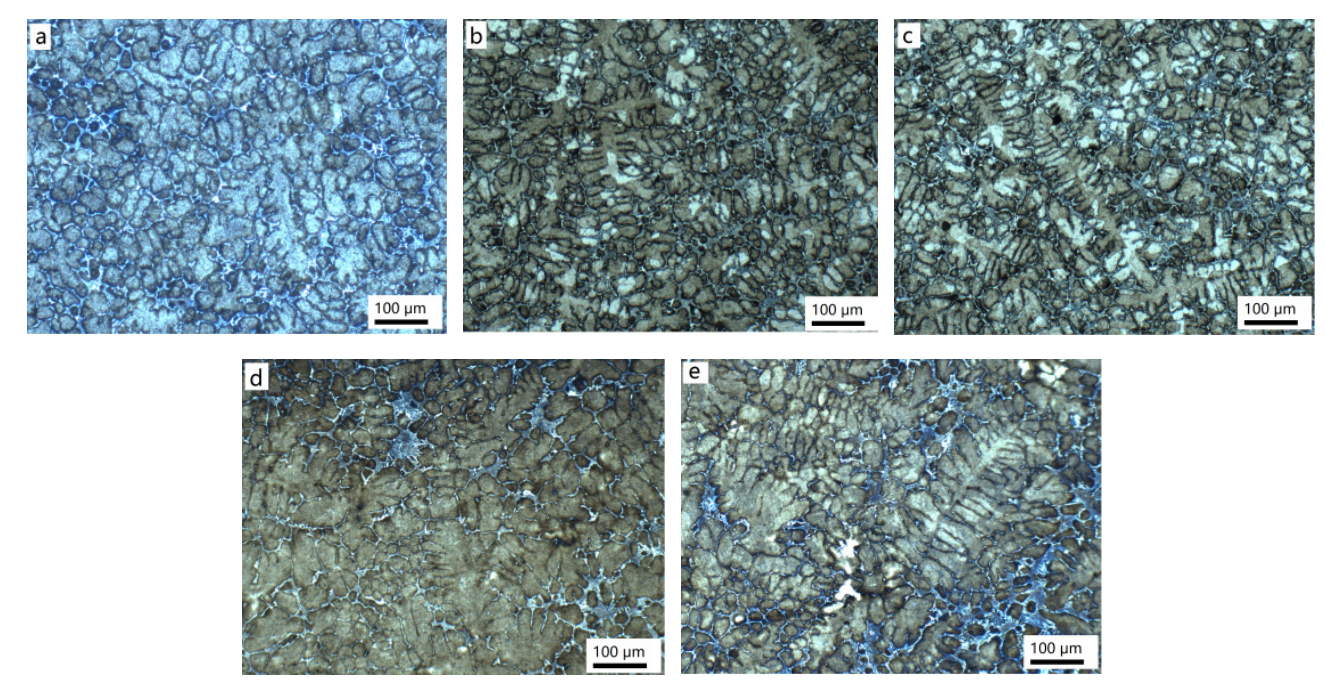

Figure 2. Microstructure $(\times 100)$ of the different samples from the M2 steel billet cast in the sand mold (a-e) for the billet from edge to center. 

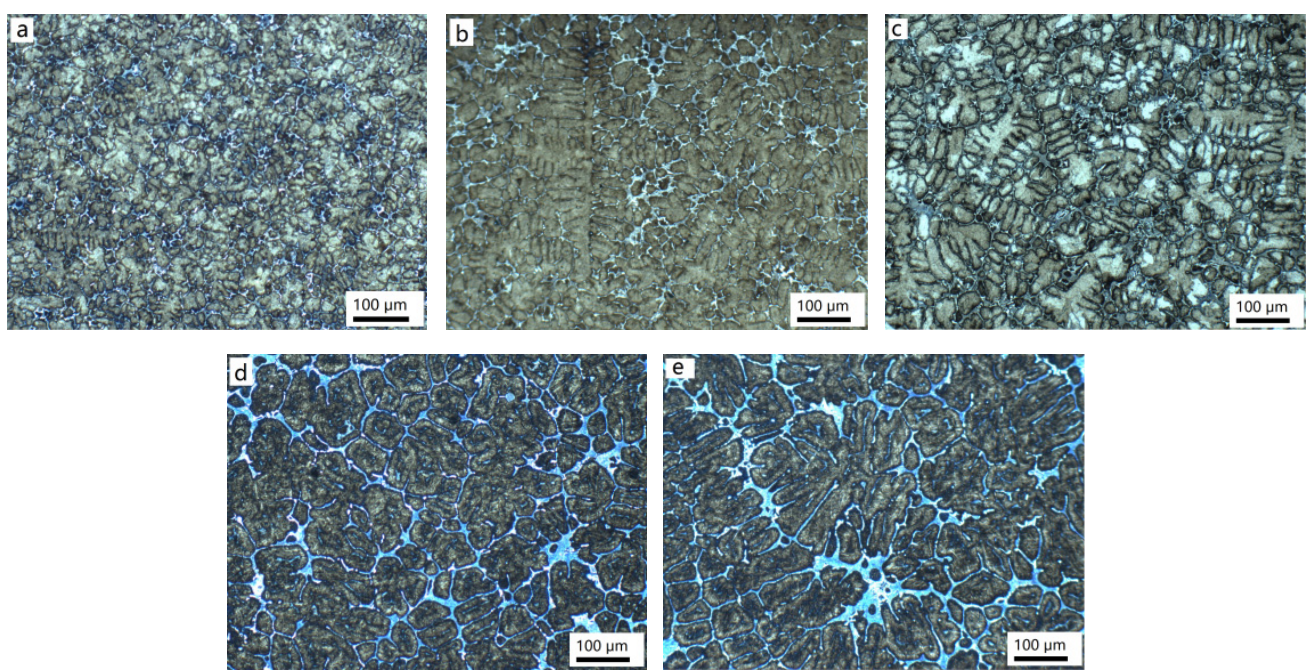

Figure 3. Microstructure $(\times 100)$ of the different samples from the M2 steel continuous casting billet (a-e) for the billet from edge to center.

The lengths of the dendrites $\left(L_{i}\right)$ were measured with MIAPS. The number of the secondary dendrite arms $\left(N_{i}\right)$ of every dendrite was counted. The statistical process is shown in Figure 4 . The $\lambda_{2}$ values of different samples of the billets can be calculated by Equation (3). The computed results are shown in Figure 5. Carrying the calculation results of Figure 4 into Equation (2), the cooling rate of each sample can be obtained. The cooling rates of each sample are shown in Figure 6.

$$
\lambda_{2}=\frac{\sum L_{i}}{\sum N_{i}}
$$

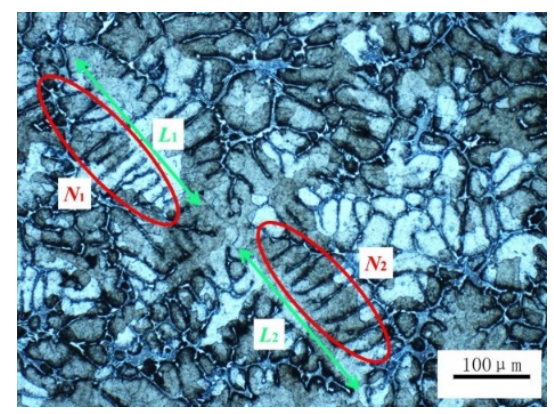

Figure 4. Measurement of the lengths of the dendrites ( $\mathrm{Li})$ and the number of secondary dendrite arms (Ni).

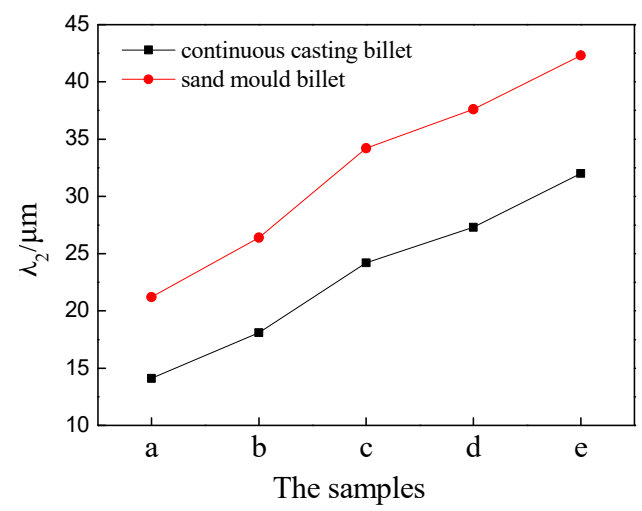

Figure 5. $\lambda_{2}$ of the different samples from the M2 steel billets. 


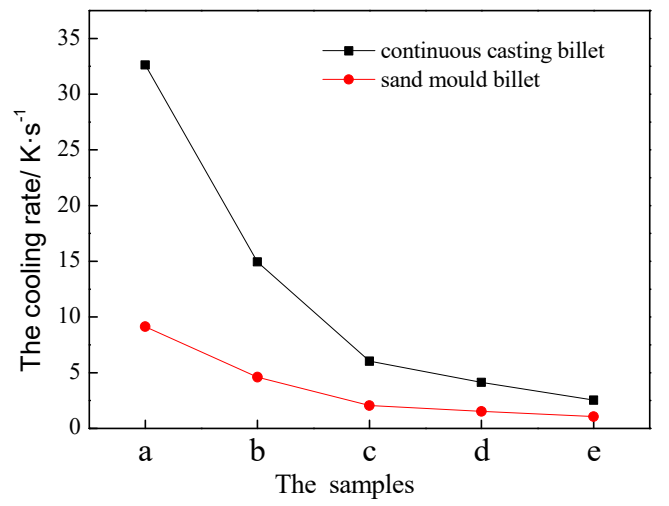

Figure 6. Calculated cooling rate of the different samples of M2 steel billets.

Table 2 lists the cooling rate ratio and the $\lambda_{2}$ ratio between continuous casting billet and sand mould ingot. The cooling rate of the (e) sample from the continuous casting billet is 2.39 times as large as that of the sand mould billet, which is 3.58 times lower than that of the (a) sample. Although the cooling rate increases by 2.39 times at the centre of the billet, the size and distribution of the carbides and grains clearly improved. These data are introduced in the next section.

Table 2. Ratios of $\lambda_{2}$ and calculated cooling rate for the different samples of billets cast with the continuous caster and sand mold.

\begin{tabular}{ccccccc}
\hline Ratios & a & b & c & d & e & Average \\
\hline$\frac{\lambda_{2} \text { (continuous casting billet) }}{\lambda_{2} \text { (sand mould ingot) }}$ & 0.67 & 0.69 & 0.71 & 0.73 & 0.76 & 0.712 \\
$\frac{\mathrm{dT} / \mathrm{dt}(\text { continuous casting billet) }}{\mathrm{dT} / \mathrm{dt}(\text { sand mould ingot) }}$ & 3.58 & 3.25 & 2.95 & 2.72 & 2.39 & 2.98 \\
\hline
\end{tabular}

\subsection{Permeability Calculation and Distribution of Carbides}

The uniformity of the eutectic carbide distribution is an important factor that affects the quality of tool steel. The permeability of the mushy zone performs an important function in the uniformity of eutectic carbide distribution.

The solid-liquid two-phase region of the solidification front is called the mushy zone. The solidus temperature of M2 steel is $1230^{\circ} \mathrm{C}$ and the liquidus temperature is $1430^{\circ} \mathrm{C}$. The mushy zone of the M2 steel solidification process is wide. The mushy zone is the main region of select crystallization, so it is the main area of solute segregation. The mushy zone of M2 steel comprises dendrites and a solute enriched liquid. The resistance of the dendrites to the flow of solute enriched liquid can be described by the permeability. An increased permeability results in an increased ability of the solute liquid to become enriched through the dendrites $[22,23]$. This causes enrichment of the solute elements in the center of the billet, while a lower permeability can effectively reduce the central segregation. The permeability in the mushy zone of the metal solidification process was calculated by the Kozeny-Carman Equation (4) as follows:

$$
K_{P}=\frac{\left(1-f_{s}\right)^{3}}{C_{K C} \times S_{0}^{2} \times f_{s}^{2}}
$$

where $K_{p}$ is the permeability in the mushy zone, $\mu \mathrm{m}^{2} ; f_{\mathrm{s}}$ is the solid phase fraction; $S_{0}$ is specific surface area of the dendrite; and $C_{\mathrm{KC}}$ is the Kozeny-Carman constant, which, here, has a value of 5.

Ahmad et al. [24] obtained Equation (5) for $S_{0}$ under the assumption that the dendrite is a uniform sphere:

$$
S_{0}=6 / \lambda_{2}
$$


Upon putting Equation (5) into Equation (4), Equation (6) can be obtained as follows:

$$
K_{P}=\frac{\lambda_{2}^{2} \times\left(1-f_{s}\right)^{3}}{180 \times f_{s}^{2}}
$$

where the value of $f_{\mathrm{s}}$ is 0.8 and $\lambda_{2}$ is the secondary dendrite arm spacing, $\mu \mathrm{m}$.

From Equation (6), it can be seen that permeability is proportional to the square of $\lambda_{2}$. An increase in $\lambda_{2}$ increases the permeability, which improves the liquidity of the solute enriched liquid; this situation causes substantial center segregation. The permeability at the corresponding sample can be calculated by Equation (6) on the basis of the measured results of $\lambda_{2}$ in different samples from the M2 steel billet in Figure 5 and the results are shown in Figure 7.

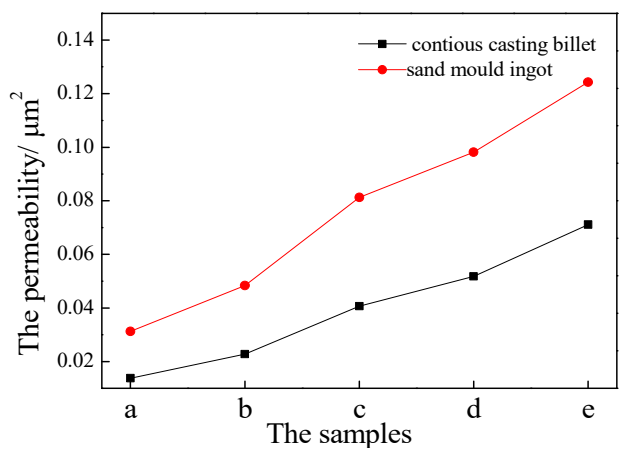

Figure 7. The permeability of the different samples from the M2 steel billets.

The average permeability of the continuous casting billet and sand mold billets was $4.0 \times 10^{-2} \mu \mathrm{m}^{2}$ and $7.7 \times 10^{-2} \mu \mathrm{m}^{2}$, respectively, and the permeability in the continuous casting billet was less than that at the corresponding position in the billed from the sand mold. It can be inferred that the content of the carbide in the center area of the sand mold billet was greater than that of the continuous casting billet. This is because the permeability was larger in the mushy zone, the fluidity of the solute-enriched liquid in the mushy zone was better and the solute-enriched liquid flowed into the center of the billet. The cooling rate had an important effect on the nucleus formation rate of dendrites during the M2 steel solidification process. It can be concluded that the size of the carbide was fine because the cooling rate was larger in the continuous casting billet. Based on the theory above, it can be determined that the center carbon segregation of a continuous casting billet is lower than that of a sand mold billet.

To verify the theory above, the carbide phase in the samples from the two billets was extracted using MIAPS, as shown in Figures 8 and 9, the composition of e1 position was determined by scanning electron microscopy and was determined to be carbide, as shown in Figure 8e1. The carbide phase area fraction was counted. The result is shown in Figure 10.

From Figures 8 and 9, it can be seen that eutectic carbides in the cast M2 high-speed steel present a network distribution. At the same time, the distribution of the carbides in the continuous casting billet was more uniform than that in the sand mold billet. The thickness of the reticulate carbide network of the different samples in the continuous casting billet is smaller than that of the corresponding positions from the billet cast in the sand mold. This is because the cooling rate in the sand mold is lower than that during continuous casting and the nucleus formation rate of dendrite is therefore lower. Thus, the dendrites are coarser and the space between the dendrites is larger, which leads to the large size of the carbides.

From Figure 10, it can be seen that the area fractions of the carbides in the samples from the continuous casting billet are lower than those of the corresponding positions of the sand mold billet. The average area fraction of the carbides in the sand mold and continuous casting billets were calculated to be 0.19 and 0.12 , respectively. Thus, it can be concluded that the cooling rate can effectively reduce the average content of carbides. The carbide area fraction in the center of the sand mold billet is 
as high as 0.24 , which increased by $27.7 \%$ compared with the average area fraction of the carbides (0.19) - the carbide area fraction in the center of continuous casting billet is 0.16 , compared with the average carbide area fraction (0.12), which increased by $25.4 \%$. The uniformity of the eutectic carbide distribution in the continuous casting billet is better than that of the sand mold billet. The analysis above shows that the continuous casting process can effectively prevent center carbon segregation and improve the uniformity of the eutectic carbide distribution.
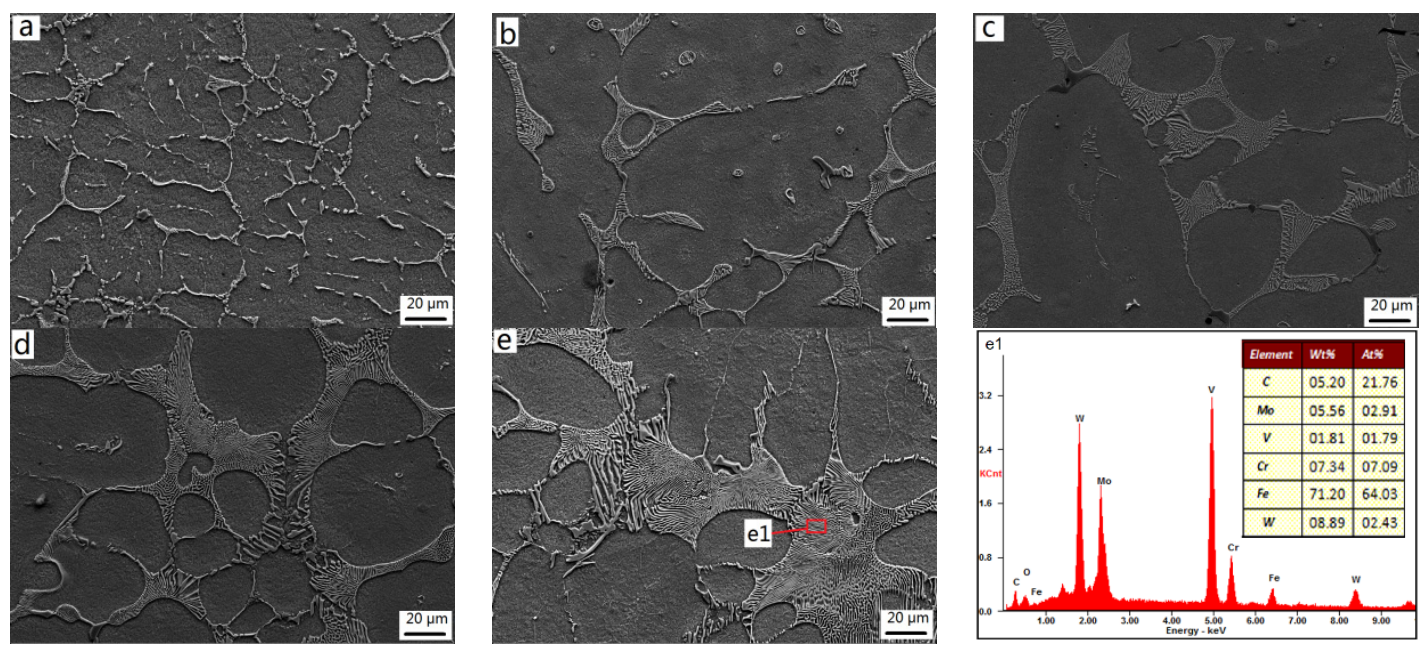

Figure 8. Distribution of carbides in the different samples from the sand mold billet $(\mathbf{a}-\mathbf{e} \times 500$ for the billet from edge to center, $\mathbf{e} 1$ for the composition of the carbide determined by scanning electron microscopy (SEM)).
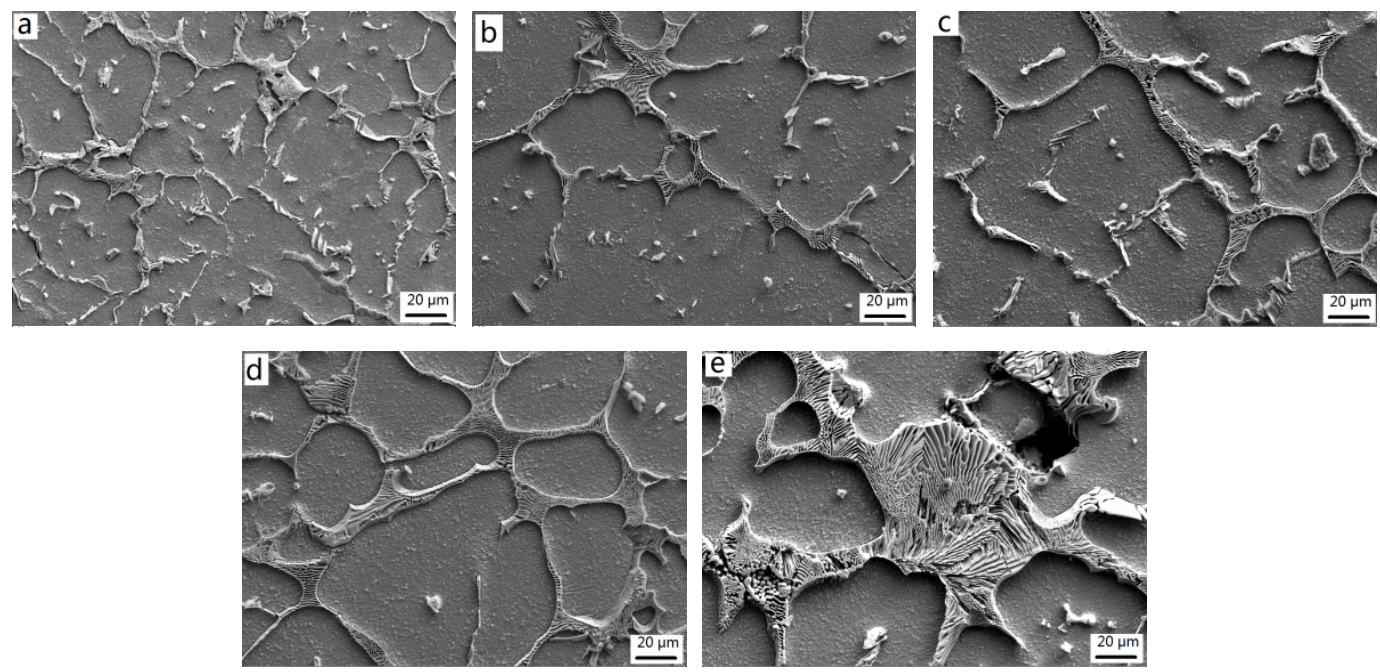

Figure 9. Distribution of carbides in the different samples from the continuous casting billet $(\mathbf{a}-\mathbf{e} \times 500$ for the billet from edge to center).

As shown in Figure 10, it can also be seen that the carbide area fraction in the (b) sample is the lowest of the two billets. This is because the cooling rate in the (a) sample was large, which led to a low $\lambda_{2}$, which indicates that the permeability was small. The solute enriched liquid in the (a) sample cannot flow to the (b) sample. When the solidification front moved to the (b) sample, the cooling rate decreased and the $\lambda_{2}$ and the permeability increased. The solute enriched liquid in the (b) sample can flow to sample (c), so the carbide area fraction in the (b) sample is the lowest. The liquidity of the solute-enriched liquid of the (a) sample in the continuous casting billet was obstructed effectively and the obstruction effect was better than that of the sand mold billet. 


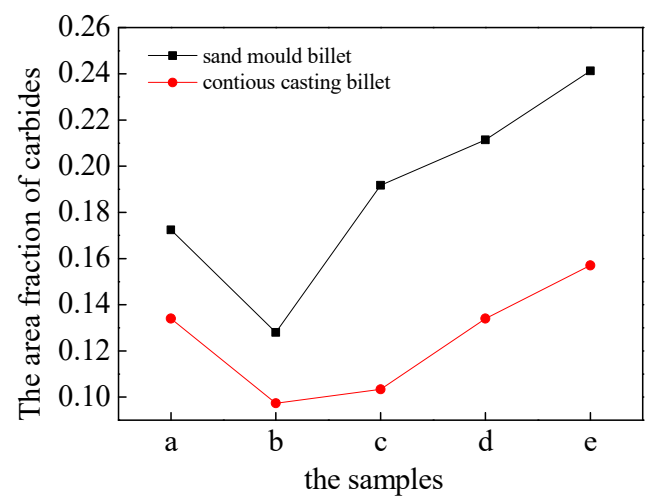

Figure 10. Area fraction of carbide in the different samples of the M2 steel billets.

\subsection{The Grain Size Measurement}

The samples of two billets were ground and polished and etched in a $10 \% \mathrm{FeCl}_{3}$ solution. The microstructures of the samples were observed. At the same time, the grain size was counted using the MIAPS method. The process for the statistical grain size analysis is shown in Figure 11. The statistical results are shown in Figure 12.
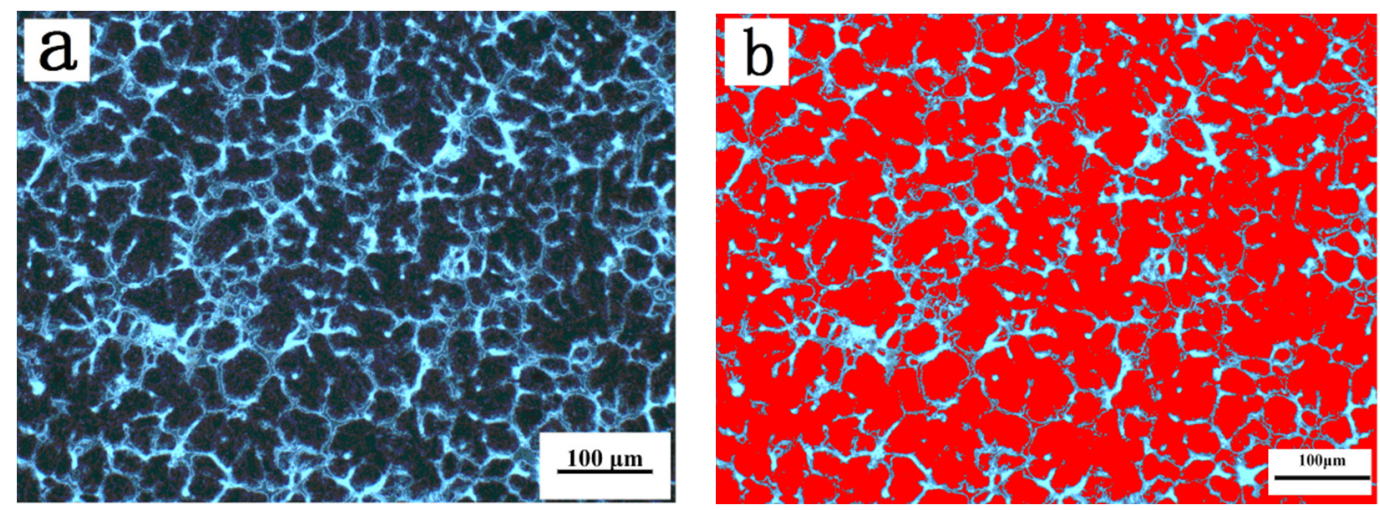

Figure 11. Grain size statistical analysis result: $(\mathbf{a})$ original microstructure $(\times 100)$ and $(\mathbf{b})$ microstructure $(\times 100)$ after processing.

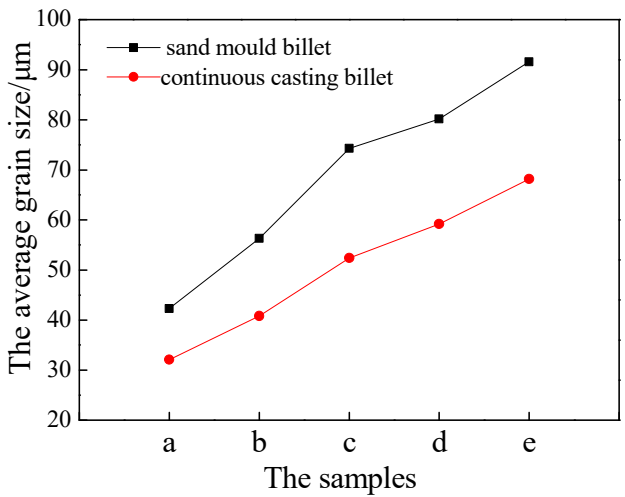

Figure 12. The grain size at different positions in sand and continuous casting billets.

Figure 12 shows that the grain sizes in the continuous casting billet are smaller than those in the sand mold billet. The average grain size of the sand mold billet is approximately $69.4 \mu \mathrm{m}$, while the average grain size of the continuous casting billet is approximately $50.54 \mu \mathrm{m}$. Compared with that of the sand mold billet, the average grain size of the continuous casting billet is reduced by approximately $26.7 \%$. The grain size of the samples increased by 2.12 times from the edge to center in the continuous 
casting billet and it increased by 2.16 times in the sand mold billet. The continuous casting process can effectively refine the grain size but it did not have a distinct effect on the grain distribution uniformity.

The analysis above shows that as the cooling rate increases, the grain size is reduced. There is almost a one-to-one correlation between the cooling rate and grain size in the M2 steel. According to the cooling rates of the samples in Figure 6 and the grain size of the samples in Figure 12, the relationship between cooling rates and grain sizes of M2 steel during the solidification process can be obtained, as shown in Figure 13. Then, the data from Figure 13 can be fit using Equation (7) as follows:

$$
l=92.3\left(\frac{\mathrm{d} T}{\mathrm{~d} t}\right)^{-0.318}
$$

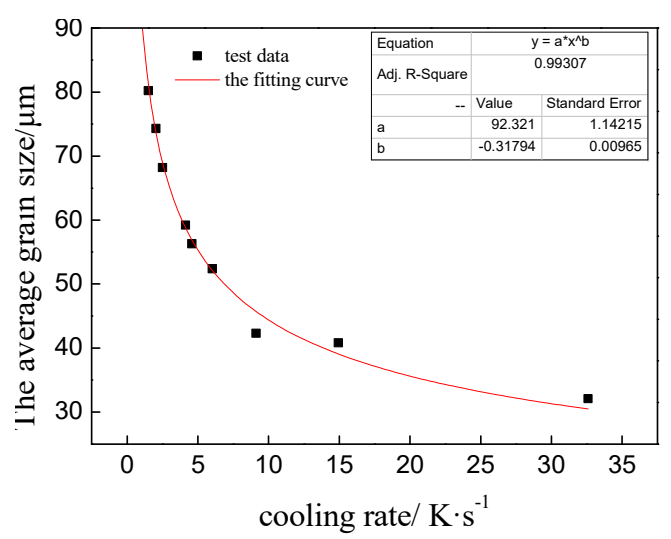

Figure 13. Relationship between grain size and cooling rate of M2 steel during solidification.

In Equation (7), $\mathrm{d} T / \mathrm{d} t$ is the cooling rate, $\mathrm{K} \cdot \mathrm{s}^{-1}$; and $l$ is the average grain size, $\mu \mathrm{m}$. The degree of the fit of Equation (7) reached 0.99, so the grain size of M2 steel can be calculated according to the cooling rate through Equation (7). Note that Equation (7) was obtained with the test data, where the cooling rate $\mathrm{dT} / \mathrm{d} t$ was between $1.05 \mathrm{~K} / \mathrm{s}$ and $32.6 \mathrm{~K} / \mathrm{s}$. Thus, Equation (7) only applies to M2 steel.

From Figure 13 and Equation (7), it can be seen that the increase in the cooling rate and the grain size decreases. The relationship of the cooling rate and grain size is non-linear. When the cooling rate is low, a small increase in the cooling rate can lead to a significant decrease in the grain size. When the cooling rate is large and continues to increase, the decrease in the grain size is not particularly evident. Based on Figure 6, the cooling rates in the center of the continuous casting billet and sand mold billet are $2.52 \mathrm{~K} \cdot \mathrm{s}^{-1}$ and $1.05 \mathrm{~K} \cdot \mathrm{s}^{-1}$, respectively. From Figure 12 , the grain size decreases from $91.6 \mu \mathrm{m}$ to $68.2 \mu \mathrm{m}$, respectively, which indicates a reduction of $25.5 \%$. Thus, an appropriate increase in the cooling rate can effectively reduce the grain size in the center of the M2 steel billet.

\section{Conclusions}

(1) The $\lambda_{2}$ values of the round M2 steel billets with a cross-section diameter of $100 \mathrm{~mm}$ cast with a sand mold and continuous caster are $37.34 \mu \mathrm{m}$ and $21.14 \mu \mathrm{m}$, respectively, and the cooling rate is $3.6 \mathrm{~K} \cdot \mathrm{s}^{-1}$ and $12.0 \mathrm{~K} \cdot \mathrm{s}^{-1}$, respectively.

(2) The average permeability of the M2 steel billets cast with a sand mold and continuous caster is $7.7 \times 10^{-2} \mu \mathrm{m}^{2}$ and $4.0 \times 10^{-2} \mu \mathrm{m}^{2}$, respectively. The area fractions of carbides are 0.24 and 0.16 , respectively, at the center of the billet cast with a sand mold and continuous caster. The continuous casting process can significantly reduce the permeability and reduce the central carbon segregation.

(3) The average grain size of billets cast with sand mold and continuous caster is $69.4 \mu \mathrm{m}$ and $50.5 \mu \mathrm{m}$, respectively. Compared with the sand mold billet, the grain size at the center of the continuous casting billet was reduced by $25.5 \%$. 
(4) The relationship between the grain size and the cooling rate of M2 steel during the solidification process can be expressed as $l=92.3\left(\frac{\mathrm{d} T}{\mathrm{~d} t}\right)^{-0.318}$.

Author Contributions: Conceptualization, J.Z. and Z.Z.; Methodology, J.Z., Y.W. and W.W.; Validation, Z.Z., Y.W. and W.W.; Formal analysis, J.Z. and Z.Z.; Investigation, J.Z., Y.W. and W.W.; Data curation, Z.Z., Y.W. and W.W.; Writing一original draft preparation, J.Z. and Z.Z.; Writing-review and editing, J.Z. and Z.Z.

Funding: This research was funded by the National Key R\&D Program of China, grant number 2017YFB0304600, and the Major Program of Science and Technology of Shanxi Province, Grant No. 20181101015.

Acknowledgments: For completing this article, I would like to express my great gratitude to those who have helped me a lot in the research. I also thank National Engineering and Research Center for Continuous Casting Technology, Center Iron and Steel Institute, which provided materials and test equipment.

Conflicts of Interest: The authors declare no conflict of interest.

\section{References}

1. Kumar, S.; Nagraj, M.; Bongale, A.; Khedkar, N. Deep cryogenic treatment of AISI M2 tool steel and optimisation of its wear characteristics using Taguchi's approach. Arabian J. Sci. Eng. 2018, 43, 4917-4929. [CrossRef]

2. Ji, Y.L.; Zhang, W.; Chen, X.Y.; Li, J.G. Increasing solidification rate of M2 high-speed steel ingot by fusible metal mold. Acta Metall. Sinica 2016, 29, 382-387. [CrossRef]

3. Zhou, X.F.; Fang, F.; Jiang, J.Q.; Zhu, W.L.; Xu, H.X. Study on decomposition behaviour of $\mathrm{M}_{2} \mathrm{C}$ eutectic carbide in high speed steel. Mater. Sci. Technol. 2012, 28, 1499-1504. [CrossRef]

4. Zhou, X.F.; Liu, D.; Zhu, W.L.; Fang, F.; Tu, Y.Y.; Jiang, J.Q. Morphology, microstructure and decomposition behavior of $\mathrm{M}_{2} \mathrm{C}$ carbides in high speed steel. J. Iron. Steel Res. Int. 2017, 24, 43-49. [CrossRef]

5. Liu, Z.H.; Zhang, D.Q.; Chua, C.K.; Leong, K.F. Crystal structure analysis of M2 high speed steel parts produced by selective laser melting. Mater. Charac. 2013, 84, 72-80. [CrossRef]

6. Liu, Q.X.; Lu, D.P.; Lu, L.; Hu, Q.; Fu, Q.F.; Zhou, Z. Effect of mischmetal on as-cast microstructure and mechanical properties of M2 high speed steel. J. Iron. Steel Res. Int. 2015, 22, 245-249. [CrossRef]

7. Ji, Y.; Zhou, N.B.; Sun, X.H.; Jiang, B.; Xiao, L.L.; Liu, Y.Z. Influence of cooling rate and chemical composition on phase transformation and hardness of C70S6 steel. Mater. Sci. Forum 2017, 898, 1202-1207. [CrossRef]

8. Randelius, M.; Sandström, R.; Melander, A. Fatigue strength of conventionally cast tool steels and its dependence of carbide microstructure. Steel Res. Int. 2012, 83, 83-90. [CrossRef]

9. Chaus, A.S.; Kuhajdová, A.; Dománková, M.; Dománková, M. Effect of multiple local repairs on microstructure and mechanical properties of T24 steel welded joint. J. Mater. Eng. Perform. 2018, 27, 1-11. [CrossRef]

10. Huo, Y.; Lin, J.; Bai, Q.; Wang, B.; Tang, X.; Ji, H. Prediction of microstructure and ductile damage of a high-speed railway axle steel during cross wedge rolling. J. Mater. Process. Technol. 2017, 239, 359-369. [CrossRef]

11. Ma, S.Q.; Xing, J.D.; He, Y.L.; Li, Y.F.; Fu, H.G.; Huang, Z.F.; Gao, Y.F. Effect of heat treatment on microstructures and mechanical properties of al-modified boron high speed steel. Key Eng. Mater. 2017, 732, 24-31. [CrossRef]

12. Fu, H.G.; Liu, X.N.; Yang, Y.W.; Cheng, X.L.; Qu, Y.H. Effect of Heat Treatment on microstructure and properties of high boron-high speed steel. Trans. Indian Inst. Met. 2018, 71, 2423-2432. [CrossRef]

13. Xu, D.M.; Wang, G.Q.; Chen, X.; Li, Y.X.; Liu, Y.; Zhang, H.W. Effects of alloy elements on ductility and thermal conductivity of compacted graphite iron. China Foundry 2018, 15, 189-195. [CrossRef]

14. Wang, M.M.; Zhang, F.C.; Yang, Z.N. Effects of alloying elements and cooling rates on the high-strength pearlite steels. Mater. Sci. Technol. 2017, 33, 1673-1680. [CrossRef]

15. Chaus, A.S. Microstructural and properties evaluation of M2 high speed steel after inoculating addition of powder W and WC. Mater. Sci. Technol. 2014, 30, 1105-1115. [CrossRef]

16. Gill, S.S.; Singh, R.; Singh, J.; Singh, H. Adaptive neuro-fuzzy inference system modeling of cryogenically treated AISI M2 HSS turning tool for estimation of flank wear. Expert Syst. Appl. 2012, 39, 4171-4180. [CrossRef]

17. Zhou, X.F.; Fang, F.; Jiang, J.Q.; Zhu, W.L.; Xu, H.X. Refining carbide dimensions in AISI M2 high speed steel by increasing solidification rates and spheroidising heat treatment. Mater. Sci. Technol. 2014, 30, 116-122. [CrossRef] 
18. Katiyar, P.K.; Misra, S.; Mondal, K. Effect of different cooling rates on the corrosion behavior of high-carbon pearlitic steel. J. Mater. Eng. Perform. 2018, 27, 1-10. [CrossRef]

19. Loria, E.A. Formation of carbides during rapid solidification of M7 high-speed steel. JOM 2013, 36, 65-68. [CrossRef]

20. Halfa, H. Thermodynamic calculation for silicon modified AISI M2 high speed tool steel. JMMCE 2013, 1, 257-270. [CrossRef]

21. Mohapatra, S.S.; Ravikumar, S.V.; Pal, S.K.; Chakraborty, S. Ultra fast cooling of a hot steel plate by using high mass flux air atomized spray. Steel Res. Int. 2013, 47, 229-236. [CrossRef]

22. Yoo, H.; Viskanta, R. Effect of anisotropic permeability on the transport process during solidification of a binary mixture. Int. J. Heat Mass Transfer 1992, 35, 2335-2346. [CrossRef]

23. Ganesan, S.; Poirier, D.R. Conservation of mass and momentum for the flow of interdendritic liquid during solidification. Metall. Trans. B. 1990, 21, 173-181. [CrossRef]

24. Ahmad, N.; Rappaz, J.; Desbiolles, J.L.; Jalanti, T.; Rappaz, M.; Combeau, H.; Lesoult, G.; Stomp, C. Numerical simulation of macrosegregation: A comparison between finite volume method and finite element method predictions and a confrontation with experiments. Metall. Mater. Trans. A 1998, 29, 617-630. [CrossRef]

(C) 2019 by the authors. Licensee MDPI, Basel, Switzerland. This article is an open access article distributed under the terms and conditions of the Creative Commons Attribution (CC BY) license (http://creativecommons.org/licenses/by/4.0/). 